EUROPA REGIONUM TOM XXIII ROK 2015

DOI: $10.18276 /$ er.2015.23-27

MAŁGORZATA GAEĄZKA

Akademia Wychowania Fizycznego w Warszawie

\title{
Turystyka w gminie Izabelin w opinii społeczności lokalnej ${ }^{1}$
}

\section{Wprowadzenie}

$\mathrm{T}$ urystyka zrównoważona opiera się na próbie osiagnięcia równowagi pomiędzy elementami społecznymi, ekologicznymi oraz ekonomicznymi, w związku z czym można ją traktować jako model idealny istniejący tylko w sytuacji osiągnięcia kompromisu pomiędzy tymi elementami (grupami interesu). W artykule skoncentrowano się na jednej z grup interesu zaangażowanej w kształtowanie turystyki zrównoważonej - społeczności lokalnej gminy Izabelin, która jest jedną z ośmiu gmin związanych terytorialnie z Kampinoskim Parkiem Narodowym.

W artykule dokonano analizy badań ankietowych przeprowadzonych wśród mieszkańców gminy Izabelin, których celem było m.in. poznanie opinii tej grupy interesu na temat turystyki na terenie gminy, wpływu Kampinoskiego PN na kształt oraz rozmiary ruchu turystycznego $\mathrm{w}$ gminie, poznanie potencjalnych korzyści lub niedogodności, jakich z faktu istnienia Parku doznają mieszkańcy gminy. Badaniom poddano także stosunek administracji lokalnej do turystyki na terenie gminy oraz Kampinoskiego PN i opinię na temat możliwości i barier nadania turystyce na tym terenie zrównoważonego charakteru.

${ }^{1}$ Badania prowadzono w ramach tematu badawczego DM 20 Akademii Wychowania Fizycznego Józefa Piłsudskiego w Warszawie finansowanego przez Ministerstwo Nauki i Szkolnictwa Wyższego. 


\section{Materiały i metody}

W celu poznania opinii administracji lokalnej na temat rozwoju turystyki na terenie gminy Izabelin i Kampinoskiego PN, jak również w celu zbadania możliwości rozwoju turystyki zrównoważonej na tym terenie przeprowadzono wywiad kwestionariuszowy z przedstawicielem Urzędu Gminy Izabelin.

Badaniom poddano także mieszkańców gminy Izabelin, przeprowadzając w pierwszej połowie 2014 roku badania ankietowe, którymi objęto 114 osób. Kwestionariusze ankietowe rozprowadzane były bezpośrednio na terenach gminy, a część zamieszczona została w wersji elektronicznej na portalach społecznościowych oraz forach skupiających mieszkańców gminy. W analizie statystycznej w przypadku analizy zależności między zmiennymi jakościowymi zastosowano test niezależności chi-kwadrat na poziomie istotności 0,05 , sprawdzając siłę związku za pomocą współczynnika V Cramera oraz (przy skali porządkowej) wyznaczając współczynnik $\tau$ (tau) Kendalla. W przypadku analizy zależności między zmienną ilościową a zmienną jakościową zastosowano testy nieparametryczne Manna-Whitneya oraz test Kruskala-Wallisa (oba na poziomie istotności 0,05).

W badaniu wzięło udział 65 kobiet oraz 49 mężczyzn. Spośród przebadanych $40 \%$ stanowily osoby w wieku 45-64 lata, a następnie w przedziale wiekowym 25-44 lat (32\%), osoby po 65 roku życia (16\%) oraz ludzie młodzi do 24 roku życia (12\%). Pod względem wykształcenia przeważali respondenci z wykształceniem średnim (51\%) oraz wyższym $(30 \%)$ w stosunku do osób z wykształceniem zawodowym (15\%) i podstawowym (4\%).

Pod względem wykonywanej pracy $31 \%$ respondentów to pracownicy umysłowi, natomiast po $14 \%$ stanowili pracownicy fizyczni i uczniowie lub studenci będący na utrzymaniu rodziców. Pozostali respondenci to gospodynie domowe (12\%), emeryci lub renciści (11\%) oraz prowadzący własną działalność gospodarczą (8\%). Niewielki odsetek przebadanych stanowili bezrobotni (4\%) i rolnicy $(3 \%)$.

Większość przebadanych (56\%) stanowili mieszkańcy terenów Kampinoskiego PN. Pozostali respondenci to mieszkańcy bliższej otuliny do $1 \mathrm{~km}$ od granic Parku (33\%) i powyżej $1 \mathrm{~km}$ od jego granic (11\%). Co ważne, zdecydowana większość ankietowanych (79\%) mieszka w swojej miejscowości na terenie gminy Izabelin od urodzenia i nie przewiduje przeprowadzki do innej miejscowości. 


\section{Turystyka w gminie Izabelin}

Gmina Izabelin położona jest przy północno-zachodniej granicy Warszawy i sąsiaduje z dzielnicą Bielany. Dysponuje ona ogromnym potencjałem turystycznym składającym się przede wszystkim z sąsiedztwa Kampinoskiego PN, który zajmuje około $85 \%$ powierzchni całej gminy ${ }^{2}$.

Do znakomitych walorów przyrodniczych gminy zaliczają się głównie cztery Obszary Ochrony Ścisłej Kampinoskiego PN położone na jej terenie: Sieraków, Cyganka, Zaborów Leśny i Kalisko, prezentujące charakterystyczne dla Puszczy Kampinoskiej zespoły wydm, bagien i zbiorowisk leśnych ${ }^{3}$. Równie znaczące są walory kulturowe i historyczne o czym świadczy chociażby fakt, iż na terenie gminy znajduje się Truskaw - najstarsza wieś w Puszczy Kampinoskiej, o której wzmianki pochodzą z $1419 \mathrm{r}^{4}$

Położenie w bezpośrednim sąsiedztwie Warszawy oraz Kampinoskiego PN istotnie wpływa na wszystkie dziedziny życia w gminie oraz kształtuje kierunki dalszego rozwoju. Z roku na rok liczba mieszkańców gminy wzrasta, czego główną przyczyną jest migracja ludzi ze stolicy, którzy „uciekając” przed życiem w wielkim mieście szukają cichego miejsca nieopodal Warszawy. W 2013 roku gminę zamieszkiwało 10523 osób, co oznacza, że od momentu powstania gminy, tzn. od 1995 roku, liczba ludności wzrosła o przeszło $40 \%{ }^{5}$.

Gmina Izabelin posiada opracowaną strategię rozwoju ${ }^{6}$, w której rozwój zrównoważony uznano za podstawę zarządzania oraz element kształtowania procesów rozwoju społeczno-gospodarczego. Gmina nie posiada natomiast odrębnego dokumentu dotyczącego rozwoju turystyki, a kwestie te poruszane są w ogólnej strategii, w której jednak zajmują miejsce zupełnie poboczne, co może dziwić biorąc pod uwage, iż jest to gmina z bardzo dużym potencjałem turystycznym.

\footnotetext{
${ }^{2}$ Powierzchnia gminy wynosi $65 \mathrm{~km}^{2}$, z czego około $56 \mathrm{~km}^{2}$ zajmują tereny Kampinoskiego PN. Pozostała część obszaru gminy wchodzi w skład otuliny. Największą część terenów Kampinoski PN zajmuje właśnie $\mathrm{w}$ gminie Izabelin, która jest jednocześnie jedną z mniejszych gmin związanych terytorialnie z Parkiem. Dane z wyników badań ankietowych przeprowadzonych w gminie oraz z pracy: A. Hibszer, M. Markowski, Czy możliwe jest ograniczenie presji urbanizacyjnej - głównego zagrożenia antropogenicznego Kampinoskiego Parku Narodowego?, Prądnik. Prace i Materiały Muzeum im. Władysława Szafera, nr 20, 2010, s. 216.

${ }^{3}$ Strategia rozwoju gminy Izabelin do 2020 roku, Respublic, Warszawa 2010, s. 50.

${ }^{4}$ L. Herz, Puszcza Kampinoska, Sport i Turystyka, Warszawa, 1990, s. 262.

${ }^{5}$ Powierzchnia i ludność w przekroju terytorialnym w 2014 r., GUS, Warszawa 2014, s.111.

${ }^{6}$ Strategia rozwoju...
} 
W gminie nie prowadzi się badań dotyczących kwestii turystycznych, m.in. liczby odwiedzających, w związku z czym gmina nie posiada dokładnych danych statystycznych dotyczących wielkości ruchu turystycznego na jej terenie. Mimo to przedstawiciele gminy uważają, że w ciągu ostatnich 5 lat zaobser-wowano nieznaczny wzrost zainteresowania walorami turystycznymi gminy, a odwiedzający kierują się głównie motywami typowo rekreacyjnymi. Jednocześnie władze uważają, że nastawienie mieszkańców gminy do turystów w ostatnich latach zmieniło się pozytywnie i oceniają je jako przyjazne. Co ciekawe, władze gminy Izabelin uważają, że gdyby Puszcza Kampinoska nie była objęta ochroną w postaci parku narodowego, turystów byłoby prawdopodobnie więcej.

Wśród działań podejmowanych w okresie ostatnich 5 lat w zakresie tworzenia odpowiednich warunków dla rozwoju turystyki na terenie gminy przedstawiciele władz wskazywali na wydawanie materiałów informacyjno-rekla-mowych dotyczących walorów turystycznych gminy, wspieranie działań proekologicznych, a także wprowadzanie różnych form edukacji proekologicznej w szkołach (w tym zajęcia w Centrum Edukacji Kampinoskiego PN) oraz dbałość o harmonijny i estetyczny wygląd terenów zielonych i przyrodniczych. Ponadto wyremontowano kilka odcinków dróg leżących na terenie gminy i sfinansowano budowę parkingów.

Głównymi formami współpracy oraz wymiany pomysłów i poglądów dotyczących turystyki pomiędzy mieszkańcami a administracją lokalną są kontakty za pośrednictwem strony internetowej oraz organizowanie wspólnych akcji. Niestety nie są organizowane systematyczne, bezpośrednie spotkania z mieszkańcami, na których poruszane byłyby różne problemy z życia gminy.

Zdaniem administracji lokalnej głównymi utrudnieniami, na jakie napotykają mieszkańcy gminy z faktu istnienia na jej terenie Kampinoskiego PN, są zakaz poruszania się po niektórych drogach, ograniczenia w zakresie działalności gospodarczej oraz utrudnienia w rozwoju budownictwa.

Jednocześnie jako podstawową barierę utrudniającą rozwój turystyki wymieniano bezpośrednie sąsiedztwo aglomeracji warszawskiej, a także niedorozwój sieci komunikacyjnej na terenie miasta w postaci małej liczby ścieżek rowerowych doprowadzonych do granic miasta i zatłoczone oraz niedostosowane do ruchu codziennego i weekendowego drogi wyjazdowe. 


\section{Turystyka w gminie Izabelin w opinii jej mieszkańców}

Na wstępie należy zaznaczyć, iż w żadnym z poniższych przypadków nie stwierdzono istotnych statystycznie różnic pomiędzy przyjętymi zmiennymi (płeć, wiek, miejsce zamieszkania na terenie gminy).

Wśród najczęściej wymienianych przez respondentów korzyści zamieszkiwania na terenie Kampinoskiego PN lub w jego otulinie znalazła się możliwość spacerowania i uprawiania rekreacji na świeżym powietrzu, ponieważ wśród przebadanych odpowiednio $81 \%$ i $63 \%$ uznało, iż są to zdecydowanie największe korzyści, jakie daje im zamieszkiwanie na tym terenie. Powyższe odpowiedzi respondentów potwierdzają pojawiające się poglądy, iż Kampinoski PN traktowany jest przez ludność miejscowa, jako zwykły las lub park miejski, miejsce odpowiednie na spacer. $\mathrm{Z}$ drugiej strony uważany jest za idealne miejsce do zamieszkania, zwłaszcza dla osób ceniących sobie spokój, walory przyrodnicze i bliskość dużego miasta. Inne, mniej znaczące dla respondentów korzyści, zaprezentowano w tabeli 1.

Tabela 1

Korzyści zamieszkiwania na terenie gminy Izabelin

\begin{tabular}{|c|c|c|c|c|c|c|c|c|c|c|c|c|}
\hline \multirow{2}{*}{$\begin{array}{l}\text { Korzyści z zamieszkiwania na } \\
\text { terenie lub w otulinie KPN: }\end{array}$} & \multicolumn{2}{|c|}{ Zdec. nie } & \multicolumn{2}{|c|}{ Nie } & \multicolumn{2}{|c|}{ Średnio } & \multicolumn{2}{|c|}{ Tak } & \multicolumn{2}{|c|}{ Zdec. tak } & \multicolumn{2}{|c|}{ Razem } \\
\hline & $\mathrm{N}$ & $\%$ & $\mathrm{~N}$ & $\%$ & $\mathrm{~N}$ & $\%$ & $\mathrm{~N}$ & $\%$ & $\mathrm{~N}$ & $\%$ & $\mathrm{~N}$ & $\%$ \\
\hline Świeże powietrze, spokój, cisza & 0 & 0 & 1 & 0,9 & 8 & 7,0 & 37 & 32,5 & 68 & 59,6 & 114 & 100 \\
\hline Spacerowanie po lesie & 0 & 0 & 0 & 0 & 3 & 2,6 & 19 & 16,7 & 92 & 80,7 & 114 & 100 \\
\hline Rekreacja na świeżym powietrzu & 0 & 0 & 0 & 0 & 4 & 3,5 & 38 & 33,3 & 72 & 63,2 & 114 & 100 \\
\hline Zbieranie grzybów i runa leśnego & 4 & 3,6 & 7 & 6,3 & 18 & 16,2 & 35 & 31,3 & 48 & 42,6 & 112 & 100 \\
\hline Pozyskiwanie drewna & 31 & 27,9 & 32 & 28,8 & 20 & 18,1 & 14 & 12,6 & 14 & 12,6 & 111 & 100 \\
\hline Zatrudnienie w KPN & 32 & 32,3 & 42 & 42,3 & 17 & 17,3 & 7 & 7,1 & 1 & 1,0 & 99 & 100 \\
\hline Działalność edukacyjna Parku & 12 & 11,5 & 17 & 16,3 & 39 & 37,5 & 22 & 21,2 & 14 & 13,4 & 104 & 100 \\
\hline Zajęcia dla dzieci i młodzieży & 10 & 10,1 & 18 & 18,2 & 30 & 30,3 & 25 & 25,2 & 16 & 16,2 & 99 & 100 \\
\hline
\end{tabular}

Źródło: opracowanie własne na podstawie wyników przeprowadzonych badań.

Najczęściej wymienianymi przez respondentów niedogodnościami wynikającymi z mieszkania na terenie Kampinoskiego PN były: ograniczenia w zakresie budownictwa w niektórych wypadkach uniemożliwiające rozbudowę istniejących budynków (41\%), zła komunikacja (stan dróg dojazdowych, natężenie ruchu, jakość połączeń komunikacyjnych - 25\%) oraz słaba infrastruktura wodociągowa i kanalizacyjna (21\%)

Wyniki badań pokazały, iż respondenci czują się związani z miejscem swojego zamieszkania, gdyż taki sam odsetek (po 39,5\%) identyfikuje się z nim 
bardzo mocno. Należy przypomnieć, iż 79\% wszystkich ankietowanych mieszka na terenie gminy Izabelin od urodzenia, stąd tak mocne więzi z tym obszarem. Jedynie $2 \%$ osób przyznało, iż przywiązanie do miejsca zamieszkania jest słabe.

Zbadano także, jaką według mieszkańców funkcję spełnia Kampinoski PN w stosunku do społeczeństwa i społeczności lokalnych. Najczęściej wybieranymi (po 93\% wskazań) były opinie, iż Park jest szansą na czyste środowisko oraz zachowanie cennych walorów przyrodniczych, które dzięki ochronie będą cieszyć nie tylko obecne, lecz również przyszłe pokolenia. Na kolejnym miejscu respondenci wskazywali na to, że Park jest idealnym miejscem wypoczynku dla mieszkańców i przyjezdnych (86\%), a także stanowi szansę na wypromowanie gminy poza regionem (75\%). Ważnym niewątpliwie jest, że respondenci nie postrzegają Kampinoskiego PN jako instytucji niepożądanej i odgórnie narzuconej przez państwo bez porozumienia ze społecznością lokalną oraz nie stanowi on elementu utrudniającego życie miejscowej ludności.

Wyniki badań wskazują, że $48 \%$ respondentów uważa, że turystyka wpływa na rozwój gminy, jednak nie spełnia roli wiodącej. Zdecydowanie mniejszy odsetek badanych (28\%) postrzega ją jako ważny czynnik rozwoju gminy oraz niemający większego znaczenia (14\%). Jedynie 3\% uznało, że funkcja turystyczna jest zupełnie nieistotnym elementem, niemającym wpływu na rozwój gminy.

W rozwoju turystyki na danym obszarze niewątpliwie ważnym elementem jest stosunek społeczności przyjmującej do turystów. Przebadani mieszkańcy określili swój stosunek jako obojętny (42\%) oraz przyjazny (39\%). Pozostały odsetek (10\%) przyznał, że ma niechętny stosunek do przyjezdnych, a $9 \%$ trudno było określić stopień swojego nastawienia. Warto zaznaczyć, że w większości mieszkańcy nie mają bezpośredniego kontaktu z odwiedzającymi gminę. Jednocześnie wartym odnotowania jest, że przebadani nigdy nie mieli konfliktów z odwiedzającymi tereny gminy, a najczęściej zauważanym wykroczeniem było pozostawianie przez turystów śmieci (47\%).

Respondenci oceniali wielkość ruchu turystycznego na terenie ich gminy na poziomie średnim (46\%) oraz wysokim (21\%). Znacznie mniejszy odsetek uważał, że liczba turystów jest za mała (15\%) czy za duża (10\%). Warto zwrócić uwagę, że aż $68 \%$ ankietowanych uważa, że liczbę turystów na terenie gminy powinno się pozostawić bez zmian. Pozostałe $21 \%$ opowiedziało się za zwiększeniem ruchu turystycznego, a $11 \% \mathrm{z}$ kolei za jego zmniejszeniem. Zdaniem respondentów w celu przyciagnięcia większej liczby turystów na tereny gminy powinno się m.in. poprawić infrastrukturę (84\%), wesprzeć miejscową ludność 
w rozwijaniu przedsiębiorczości (73\%), inwestować w centra turystyczno-rekreacyjne $(70 \%)$ oraz organizować szkolenia dla miejscowej ludności w zakresie otwierania i rozwijania działalności gospodarczej w turystyce (54\%).

Pomimo że z odpowiedzi respondentów niejednokrotnie wynika, że nie są oni zainteresowani zwiększeniem ruchu turystycznego $\mathrm{w}$ gminie, a jeśli już to uważają, że jest to problem władz lokalnych i jedynie samorząd może podjąć działania aby zmienić tę sytuację, to jednak mieszkańcy gminy Izabelin dostrzegają korzyści jakie może przynieść zwiększenie liczby odwiedzających gminę. Opinie respondentów były zróżnicowane, jednak największy odsetek uważa, że rozwój turystyki na terenie gminy i Parku przyczyni się głównie do zwiększenia dochodów osób prowadzących działalność usługową (74\%).

Tabela 2

Korzyści zwiększenia ruchu turystycznego w gminie

\begin{tabular}{|l|c|c|c|c|c|c|c|c|c|c|c|c|}
\hline \multirow{2}{*}{$\begin{array}{c}\text { Korzyści ze zwiększenia liczby } \\
\text { turystów w KPN: }\end{array}$} & Zdec. nie & \multicolumn{2}{|c|}{ Nie } & \multicolumn{2}{c|}{ Średnio } & \multicolumn{3}{|c|}{ Tak } & \multicolumn{2}{|c|}{ Zdec. tak } & \multicolumn{2}{|c|}{ Razem } \\
\cline { 2 - 15 } & & $\%$ & $\mathrm{~N}$ & $\%$ & $\mathrm{~N}$ & $\%$ & $\mathrm{~N}$ & $\%$ & $\mathrm{~N}$ & $\%$ & $\mathrm{~N}$ & $\%$ \\
\hline Nowe miejsca pracy & 7 & 6,6 & 15 & 14,2 & 28 & 26,4 & 48 & 45,3 & 8 & 7,5 & 106 & 100 \\
\hline Zw. dochodów w dział. usługowej & 1 & 0,9 & 6 & 5,5 & 21 & 19,3 & 69 & 63,3 & 12 & 11,0 & 109 & 100 \\
\hline Zw. wpływów do budżetu gminy & 3 & 2,8 & 9 & 8,3 & 25 & 23,2 & 57 & 52,8 & 14 & 12,9 & 108 & 100 \\
\hline Poprawa infr. i dost. komunik. & 5 & 4,6 & 14 & 12,8 & 29 & 26,6 & 50 & 45,9 & 11 & 10,1 & 109 & 100 \\
\hline Zw. liczby i dost. usług dla ludn. & 3 & 2,8 & 15 & 14,2 & 34 & 32,1 & 45 & 42,4 & 9 & 8,5 & 106 & 100 \\
\hline Zw. liczby lokali rozrywkowych & 5 & 4,7 & 17 & 16,3 & 35 & 33,3 & 41 & 39,0 & 7 & 6,7 & 105 & 100 \\
\hline Nowe i korzystne znajomości & 4 & 3,8 & 13 & 12,4 & 32 & 30,5 & 46 & 43,8 & 10 & 9,5 & 105 & 100 \\
\hline Poprawa kultury osobistej mieszk. & 10 & 9,5 & 21 & 20,0 & 41 & 39,0 & 26 & 24,8 & 7 & 6,7 & 105 & 100 \\
\hline Wzmocnienie więzi lokalnej & 11 & 10,5 & 18 & 17,1 & 42 & 40,0 & 25 & 23,8 & 9 & 8,6 & 105 & 100 \\
\hline
\end{tabular}

Źródło: opracowanie własne na podstawie wyników przeprowadzonych badań.

Respondenci widzą także w rozwoju turystyki szansę m.in. na: zwiększenie wpływów do budżetu gminnego, a co za tym idzie wzrost nakładów na poszczególne miejscowości w gminie, co przyczyni się do poprawy w nich standardu i jakości życia $(66 \%)$ oraz poprawę standardu infrastruktury i dostępności komunikacyjnej $(56 \%)$.

Wśród głównych działań, jakie powinny podejmować zdaniem respondentów władze lokalne w celu rozwoju turystyki na terenie gminy, wymieniano dbałość o ład przestrzenny i estetyczny wygląd miejscowości, co stanowi czynnik przyciagający odwiedzających (97\%) oraz możliwość pozyskiwania przez władze lokalne funduszy z Unii Europejskiej na ochronę przyrody i rozwój turystyki (97\%). Na kolejnych miejscach respondenci zwracali uwagę na potrzebę zapewnienia bezpieczeństwa, zarówno turystom, jak i miejscowej ludności (93\%), oferowanie pomocy 
osobom chcącym rozwijać działalność turystyczno- rekreacyjną (79\%) oraz na konieczność rozbudowy infrastruktury turystyczno-rekreacyjnej (73\%).

Respondenci oceniali także działania i osiagnięcia władz lokalnych w różnych dziedzinach działalności w pięciostopniowej skali. Średnio najwyżej ocenianymi okazały się kultura (średnia ocen 2,75 ), edukacja $(2,66)$ oraz ochrona środowiska $(2,32)$. Najgorzej respondenci ocenili natomiast działania władz lokalnych w zakresie transportu $(1,95)$.

Tabela 3

Ocena osiągnięć władz lokalnych

\begin{tabular}{|l|c|c|}
\hline \multicolumn{1}{|c|}{ Osiagnięcia władz lokalnych } & Średnia & Odch. std. \\
\hline Edukacja & 2,66 & $\pm 1,09$ \\
\hline Ochrona zdrowia & 2,18 & $\pm 1,13$ \\
\hline Ochrona środowiska & 2,32 & $\pm 1,05$ \\
\hline Kultura & 2,75 & $\pm 1,11$ \\
\hline Sport & 2,29 & $\pm 1,16$ \\
\hline Turystyka i rekreacja & 2,04 & $\pm 1,14$ \\
\hline Transport & 1,95 & $\pm 1,19$ \\
\hline Gospodarka komunalna & 2,10 & $\pm 1,15$ \\
\hline Porządek i bezpieczeństwo & 2,25 & $\pm 1,18$ \\
\hline
\end{tabular}

Źródło: opracowanie własne na podstawie wyników przeprowadzonych badań.

Należy zauważyć, że działania podejmowane przez administrację lokalną w zakresie rozwoju turystyki zostały ocenione na względnie niskim poziomie, ze średnią ocen jedynie 2,04. Przypomnieć jednak można, iż w strategii rozwoju gminy Izabelin turystyka nie jest dziedziną, której poświęca się dużo uwagi i zajmuje ona miejsce poboczne, stąd również ma to zapewne przełożenie na oceny ludności miejscowej.

\section{Podsumowanie}

Podsumowując, badania prowadzono wśród osób nieprowadzących działalności gospodarczej w zakresie turystyki wychodząc z założenia, że czerpanie korzyści materialnych zmienia punkt widzenia na sprawy będące przedmiotem badań.

$\mathrm{Z}$ badań można wysnuć wniosek, że respondenci zamieszkujący tereny gminy Izabelin, a tym samym okolice Kampinoskiego PN, to przede wszystkim osoby traktujące miejsce swojego zamieszkania jako typową ,sypialnię" o doskonałym położeniu niedaleko Warszawy. Przebadani są usatysfakcjonowani z miejsca zamieszkania, a główną korzyścia, jaką z tego tytułu czerpią, jest otaczająca ich przy- 
roda Kampinoskiego PN oraz możliwości uprawiania różnych form aktywności turystyczno-rekreacyjnej.

Rozwój turystyki nie jest respondentom całkowicie obojętny i postrzegaja ją jako jeden z czynników wpływających na ogólny rozwój gminy, jednocześnie opowiadając się jednak za pozostawieniem wielkości ruchu turystycznego na obecnym poziomie. Część przebadanych dostrzega korzyści płynące ze zwiększenia liczby odwiedzających tereny gminy, lecz kwestię rozwoju turystyki postrzegają jako problem administracji lokalnej, która ich zdaniem powinna podejmować działania w tym zakresie, również te polegające na motywowaniu i szkoleniu mieszkańców do prowadzenia działalności gospodarczej i usługowej związanej z turystyka.

Ważnym wydaje się fakt, że turystyka w strategii rozwoju gminy zajmuje miejsce poboczne pomimo bardzo dużego potencjału turystycznego, jakim dysponuje gmina Izabelin, opierającego się na wybitnych walorach Kampinoskiego PN. Gmina Izabelin jest gminą o typowo mieszkalnym charakterze, na który wpływ miał przede wszystkim rozwój aglomeracji warszawskiej. Władze lokalne postrzegają gminę jako kameralne miejsce zamieszkania o wysokim standardzie życia, na który wpływ ma także bliskość Kampinoskiego PN, który stanowi jeden z elementów stymulujących rozwój gospodarczy ${ }^{7}$. Wydaje się, że szansą na rozwój gminy pod względem turystycznym jest turystyka weekendowa, która wymaga jednak odpowiedniego zagospodarowania i infrastruktury, z której korzyści odnieśliby nie tylko odwiedzający, lecz także mieszkańcy, którzy mogliby prowadzić m.in. wypożyczalnie sprzętu turystyczno-rekreacyjnego czy gospodarstwa agroturystyczne. Jednak przeprowadzone badania pokazują, iż aby ten cel zrealizować, władze lokalne powinny skupić się na aktywizacji i motywacji społeczności lokalnej do otwierania tego rodzaju działalności. Warto przypomnieć, że aktywny udział społeczności lokalnej w rozwoju turystyki oraz osiagnięcie względnego kompromisu pomiędzy głównymi grupami interesu (społecznością lokalną, zarządzającymi obszarem chronionym oraz organizatorami turystyki) jest istotą nadania turystyce na danym obszarze zrównoważonego charakteru.

\section{Bibliografia}

Herz L., Puszcza Kampinoska, Sport i Turystyka, Warszawa 1990.

\footnotetext{
${ }^{7}$ Strategia rozwoju gminy Izabelin do 2020 roku, Respublic, Warszawa 2010, s. 9.
} 
Hibszer A., Markowski M., Czy możliwe jest ograniczenie presji urbanizacyjnej - głównego zagrożenia antropogenicznego Kampinoskiego Parku Narodowego?, Prądnik. Prace i Materiały Muzeum im. Władysława Szafera, nr 20, 2010.

Powierzchnia i ludność w przekroju terytorialnym w 2014 r., GUS, Warszawa 2014. Strategia rozwoju gminy Izabelin do 2020 roku, Respublic, Warszawa 2010.

\section{Tourism in Izabelin community in the opinion of the local community}

\section{Summary}

Article analyzes the survey of local communities of Izabelin, which its tourism potential draws mainly from the direct neighbourhood of the Kampinoski National Park. Purpose of the study was to know the opinion of the local communities on tourism in their community and to determine the degree of preparedness of local communities to implement the principles of sustainable tourism. Studies have shown that the respondents threat that place as a typical "bedroom" with an excellent location in close proximity of Warsaw. Respondents are very satisfied with their place of residence and they perceive a number of benefits, they might experience as a result of tourism development in their community. However, they consider that this is a local government problem and the local authority should take action in this regard.

Transleted by: Małgorzata Gałazka 